\title{
Enzyme Induction
}

National Cancer Institute

\section{Source}

National Cancer Institute. Enzyme Induction. NCI Thesaurus. Code C41564.

Enzyme Induction involves initiation of function of a biological molecule that possesses

catalytic activity. 